\title{
Using social media and apps to enhance religiosity amongst Christian youth
}

\author{
Thomas $\mathrm{MJ}^{1}$, Avinash De Sousa ${ }^{2}$ \\ ${ }^{1}$ Department of Psychology and Counseling, Don Bosco University, Guwahati, Assam \\ ${ }^{2}$ Research Associate, Department of Psychiatry, Lokmanya Tilak Municipal Medical College, Mumbai. \\ Corresponding author: Thomas MJ \\ Email-mjtomssp@gmail.com
}

\begin{abstract}
Social Media is a term that is so often used in our daily conversations. Whether we like it or not, it has become an inevitable part of our life and it is going to stay that way in the time to come. Its rapid growth and acceptability has greatly influenced human behaviour, lifestyle and thinking. Regardless of age, gender, status and geographical location, people actively get involved in different social networking sites. The speed, cost and reach captivate the users to spend more time on the social media. Whether social media is good or evil will depend on the nature of its use. This article throws some light on the increased use of social media among Christian youth, the role it plays in uniting Christian communities and its growing impact on the administering of sacraments and the conducting of church activities. Akin to general population, many church leaders like Pope, Cardinals, Bishops and Priests are part of the social media like Facebook, Twitter, Instagram, etc. Some of them use it extensively to spread the Good News and to share their messages and ideas across larger population.
\end{abstract}

Keywords: Social media, Apps, Church, Christian, youth

(Paper received $-30^{\text {th }}$ January 2018, Peer review completed $-2^{\text {nd }}$ March 2018)

(Accepted $-6^{\text {th }}$ March 2018)

\section{INTRODUCTION}

Every Christian by his/her baptism is duty bound to proclaim the Good News, i.e. the salvation offered to all through the death and resurrection of Jesus. Modern technologies like the internet and social media are effective and exciting means available at our hand to accelerate this job. One has to be brave and bold in using social media. There can be challenges and oppositions and people can be sceptical. But the time has come for us to take a closer look into the social media and its implications. Get to know the various opportunities and challenges social media offers and learn about the many thrilling ways the Gospel can be preached to more and more people.

Pope Francis, who called himself "a disaster" when it comes to technology said that the internet, social networks and text messages are "a gift of God" if used wisely. "Emails, text messages, social networks and chats can also be fully human forms of communication" [1]. The beginning verse of the Gospel of Saint John is significant when we discuss about Christian communication. Referring to Jesus Christ as the Word, John wrote: "in the beginning was the Word, and the Word was with God, and the Word was God" (John 1:1)*. The verse communicates the transformative power of communication. The Word was spoken to all and it continues to speak to all. It is the duty of the Church to use all means of communication to reach this Word to all. If we adapt the famous prayer of Saint Teresa of Avila, "Christ 
Has No Body", it would be something like this: "Christ has no online presence but yours, No blog, no Facebook page but yours... Yours are the posts through which the Gospel is shared..." [2].

However, social media is not to be considered a replacement for face-to-face pastoral care. It can only be an extension of a priest's personal presence. The question therefore is not whether to use it or not, rather how can social media enhance the way we carry out the ministry and promote the gospel values [2]. This article looks at the various ways social media enhances the religious experiences of youth, and the increasing demand for digitalization in our churches in order to stay relevant and effective.

\section{WHAT IS SOCIAL MEDIA}

According to the Merriam-Webster dictionary online, Social Media is defined as forms of electronic communication (as Web sites for social networking and microblogging) through which users create online communities to share information, ideas, personal messages, and other content (as videos) [3].

The emergence of social media began almost at the advent of internet when people started to use this medium to share information and exchange communication with each other. Although people in general tend to restrict social media to some networking websites like Facebook, WhatsApp and Twitter, social media in fact covers various services relating to content formation and sharing and exchange. This could include all types of internet forums, blogs, wikis, and podcasts among others [4].

\section{CHURCH AND SOCIAL MEDIA}

Social media empowers social change in the society. It provides a platform for people to air their thoughts and opinions and the possibility of being heard by others. Social media influences people from all walks of life including celebrities, politicians, public figures, businessmen and media tycoons in their decision making, interests and thought process [4]. Social media has undergone tremendous transformation over the years and it has brought about remarkable improvements in the lives of people.

Over the years, religious communication and activities have grown online and different religions like Christianity, Judaism, Islam, Buddhism, Hinduism, and Paganism have their online presence. Pew report [5] states that $64 \%$ (128 million) of U.S. internet users have done things online that related to religious or spiritual matters. This figure increased substantially with every successive Pew reports [5-6]. Pope John Paul II [7] exhorted the Church "to be bold and creative" in using the media. Pope Paul VI said, "The Church would feel guilty before the Lord if she did not utilize these powerful means" [8,no.45]. Different social networking sites, particularly those custom designed for religious needs would help the members to stay engaged with their religious communities and neighbourhood.

\section{ENHANCING RELIGIOUS EXPERIENCES USING SOCIAL MEDIA}

Smartphones and social media keep changing the way people practice their religion and share their values and beliefs. New online possibilities make it easier for people to communicate their views, ideas and suggestions onliturgy and worship. Even religious behaviors have been influenced by social media [9]. The two-way communication that social media offers opens up the possibility of mutual sharing and listening between the hierarchy and the faithful. Research by Cheong, Halavais and Kwon [10] on blogs related to Christianity and Teusner's [11] work on the digital networks of the emerging church movement in Australia bring out the personalization of religion through digital media. These studies show how blogs and podcasts are used as a means of narrating and reflecting on one's spiritual journey. People are also able to share bible verses of their choice on social media besides the readings of the day. Thus social media can provide more information, more view points, and more personalized sharing of faith and beliefs.

Social media offers Church the possibility of actively engaging in the liturgy and other church activities. Members can discuss about the readings and sermons, ask questions and share photos and videos of different parish activities. Besides sharing their insights from Bible, people can also share their personal religious experiences and the benefits of being part of different pious organizations of the parish. Charitable activities undertaken by social media groups do inculcate a spirit of sharing and sacrifice among the members. People who can't take up activities on their own will be empowered to do so when they are 
part of a group. Anonymityof the social media encourages members to freely share their thoughts and ask questions, which they wouldn't otherwise be comfortable asking and sharing.

\section{UTILITY OF BIBLE APPS VERSUS THE BIBLE AS A BOOK}

With the technology, we see the change in the medium-from book to digital. However, the message remains the same. Reading the Bible is more important than format used. What matters is not the format of the Bible but what makes one to read the Bible. "All Scripture is God-breathed, whether on paper or phone" Said Koh [12]. The new generation is more digital friendly and therefore more likely to use digital Bible in comparison to older generation.

Over the last decade, various Bible apps have been launched online. There are people who argue for and against the benefits of digital Bible. They both have their strengths and weaknesses. Here, we mainly focus our attention on the benefits of Bible app over Bible as a book. Bible apps have made a tremendous impact on Christian faith and the good practice of reading the Holy Bible. They make it convenient to access Bible on the smartphone. To make it more attractive, they come with impressive features like community conversations, social media sharing, bookmarking features, videos, podcasts etc. While Bible as a book does have its own symbolic qualities, today's youth feel comfortable reading the Bible on their phones as it gives them a sense of privacy.

Digital Bible is a blessing as it can be accessed and shared more easily, reproduced with low cost and carry around more conveniently. Different online versions and commentaries make the reading and study more interesting and quick. Some of the apps come with many translations of the Holy Bible with different features including offline reading. Besides, the possibility of quick search of a particular book of the Bible or a verse is easier on the digital Bible [13]. Various options to change the font and the size makes the reading more convenient and friendly.

Today most people carry their smartphones with them. So having a Bible app on the phone makes it available anytime and anywhere. Children and youth are more disposed to engage in digital reading than hard books. They are more likely to access a Bible app on the smart phone than a hard copy of the Bible. Many Bible apps now have a function called "listening module" which make the reading easier. This can be a great aid for those with reading difficulty. While waiting at a bus stop, airport or a railway station, one can listen to the Word of God meditatively.

However, it goes without saying that the Bible apps have their own drawbacks too. The feel of holding a book in the hand and the pleasure of turning the pages do certainly bring much satisfaction to the reader. Besides, there can be more distractions and less engagement when reading a digital Bible.

\section{WHY THE YOUTH TODAY PREFER DIGITAL MEDIA}

The amount of time the young people spend on digital devices is on the increase. A Pew Research Center report on internet and technology conducted in the U.S. reveals that $95 \%$ of all teens between the ages 12 17 are now online and $80 \%$ of those online teens are users of social media sites[14]. It's a challenge for parents and teachers to monitor the use of these gadgets by their children. They find it difficult to understand why much of young generation is glued to their digital devices. There is a fundamental difference in the way the new and the older generations use the social media. While the former group is considered to be "digital natives", the latter is called "digital immigrants". Therefore, naturally there are many 'how and why' questions about the new generation digital media use. The youth have greater need to be connected with their peers, establish relationships, and form their own identities. Similar to the digital media, but quite different from the older generation, today's youth is good at multi-tasking. They want to complete their tasks quickly and digital media help them fulfil this need. In fact, we live in an era where humans and technology are merging into one single entity and the youth are active members of this continuum.

Youth are connected to the digital world because of the many fascinating features and their availability on finger tips. Social media attracts the youth because they are able to interact with people from other cultures, religions, and racial backgrounds besides communicating with family, friends and dear ones. 
They provide platform for one's private expression of faith through posts, comments and messages. One can avoid the doctrine that does not appeal and stay with what is interesting and pleasing [9].

Church believes that creative use of social media can stir interest in individuals particularly among the youth to actively participate in the liturgy and worship. For those interested to participate in church activities and evangelization, social media can be of enormous help. It not only helps them to reconnect with older friends, but it also opens the possibility of reaching out to new friends and can become means to preach Christ. Social media posts can influence the views and opinions of others and bring encouragement and spiritual guidance to them. Social media prayer groups engage in praying for friends, family members, parish community, universal Church and those who request for prayers. Scripture invites: "Let us consider how we may spur one another to love and good works. Do not abandon the assemblies as some of you do, but encourage one another, and all the more since is Day is drawing near" (Hebrews 10:24-25).*

\section{NEED FOR PARISH COMMUNITIES TO GO DIGITAL}

If we want our parish community to grow, it has to embrace change according to the signs of the times. If it sticks to the old ways of doing things, it will eventually become irrelevant and outdated. As lifestyle changes, people prefer to communicate on their smartphones and social networking sites. It's faster, costeffective and easier. If parishes communicate through digital media, it will not only boost the communication aspects of the church, but it will also help the community to grow stronger and faster. It is true that initially Christians were slow to catch up with the computer and internet while the world outside was quick to embrace the new technology. But with the advancement of time, Church too has adapted to the modern technology. It feels the need to go digital and steps are being employed to stay modern. And today Christians around the world use new technologies as much as the general population. Clergy as well as the faithful use their smartphones to refer to the readings and to follow the prayers during the liturgy. Social media offers the platform for the members of the parish communities to actively engage in discussions on Church matters throughout the week. They can also post questions and have their doubts clarified besides sharing photos and videos that are relevant to their parish community. These can be done at each one's convenience. They do not have to skip or cancel other important meetings and programs to be part of the discussion. Moreover, every member has the opportunity to share and to be heard his/her opinions and suggestions. One gets the feeling of belonging to the community even when he/she is not physically present.

A lot of money, time and energy is saved with the arrival of social media. Online video conferencing provides the feeling of face-to-face conversation as if in a real world. Wide ranges of issues are discussed on the social media every moment. Church therefore has to take advantage of the media and their growing impact on the society in order to make God's word available to all the online users. Social media is an easy and inexpensive platform where Christian literature in videos, audios and in other formats can be shared. While the world around is changing so quickly with new technological innovations, Church can't stay behind. Instead Church should employ all the possible means to keep pace with the technology and make use of them for the spread of the Good News.

\section{DIGITLAZIATION TO UNITE CHRISTIAN COMMUNITIES}

Social media facilitates and mediates social relations. The new digital era has changed people's notion of friendship, relationship and community. Online communities have opened up new possibilities for social interaction, challenging traditional notions of community. "Social media has opened up yet another portal for seeing and being seen, for knowing and being known, for being in and belonging to community" [2]. Although it was difficult to distinguish between the real and virtual in the beginning, over the time it has become clearer. Today the online faithful engage in conversations on faith, spirituality, religion, and church, and benefit from the support they receive from online members, breaking all the barriers of space, time and other considerations. In fact, online communities of faith have become real to these participants [2]. Such mutual support and understanding is the result of staying connected and interacting for some period of time. Moreover, these online communities function faster than in the real world. 
Different parish churches can use internet and various internet facilitated websites and apps to share information to people in their parishes and other places. They could be information about prayer services, retreats, church feasts, seminars, charity programs, fund raising events, entertainments, etc. and can become a platform to attract youth and children to join the activities. Today digital media are the easiest and the fastest way to get across to maximum number of people.

There have been efforts to bring together different Christian communities for a common goal. Launching Ghana's maiden social media network, www.asoreba.com on $26^{\text {th }}$ December 2016, the Very Rev. Felix Tawiah Danquah, the Minister of the Mount Sinai Methodist Church International, Ghana reminded the people to make use of social media not only as an effective tool in the spreading of God's Word but also to bring non-Christians and Christians together under one community. Such gatherings aim at evangelization, networking, encouragement, sharing and experiencing different cultures globally [15]. It's natural that traditional members fear that the online communities are in some way inauthentic, impoverished and deceptive, and has the power to lead people out of the pew and away from face-to-face community. But online community is not a substitute, rather a supplement to extend offline relationships and communication in unique and new ways [16]. Social media provides opportunities for people living in distant places to reconnect with their home parishes and faith organizations. Studies have also found that online religious community is intrinsically connected to offline religious institutions and affiliation [1718].Online churches have the possibility of reaching to an entirely new audience. They can engage in evangelization with those communities that were inaccessible earlier. Smith [19] suggests that Christians should establish their strong presence on cyberspace like the missionaries of the past who travelled to new lands to proclaim the gospel. Estes [20] calls for missionaries to start building new churches inside the virtual world. Christian Church has a greater role to play in the cyberspace by demonstrating the advantages of their virtuous lifestyle and gradually share the messages to them in an attractive way using internet and social media.

\section{ENHANCING SEMINARY FORMATION THROUGH DIGITALIZATION}

Digitalization has brought about significant changes in all spheres of life including education sector. Digitalization in education has completely changed the learning and teaching process to a great extent [21].The influence of it is on the upward trend and it will continue to be so in the coming decades. Technology has made education less stressful both for the students and the teachers. Use of computers and internet has facilitated students' interest in learning. They prefer digitalized learning over traditional methods. More and more digital platforms are being introduced in schools and colleges to enhance the learning process. Internet has become the principal medium through which learning and information sharing take place today. Digitalization is a key element in seminary education as well. Since the youth of today are getting so used to learning through digital media, seminaries have to urgently adapt to the technological advancements if they want to be effective in seminary education. There are many ways the digital media can be employed to make the learning more interesting and effective. No amount of lecturing can sufficiently describe what digital presentations can do to the students. Videos and slides of important historical places of Bible and Church can be presented to make it more experiential to the recipients. Introducing E-learning will be a new step in seminary education. This will not only give them the freedom to attend classes from home but it will also increase their interest and enthusiasm [22].

Digitalization can make learning easier and interesting for the seminarians. Easy access to online libraries and research articles will help save time and energy. They can access materials sitting in the comforts of their rooms. They can also enter into discussions with their teachers and colleagues without going to the classrooms and libraries. They have the possibility of going over the materials over and again for better grasp of subjects and clarification of doubts. While digitalization increases the quality of education, it will reduce the cost of education [23].

While encouraging digitalization in our learning, educators have to ensure that certain equilibrium is maintained in the use of digital media in the classrooms. Overuse of digital content can detrimentally affect the much needed direct interaction between students and teachers. "Digitalization of Education is not just completely depending on the technology and its applications. Rather it's about using the available technology for the better enlightenment of the next peers" [24]. 


\section{EDUCATING SEMINARIANS ON SOCIAL MEDIA}

Seminary formation should aim at educating seminarians about the disciplined and prudent use of social media. They are not to be prevented to use, rather prepare them to use it judiciously and creatively for the spread of good messages, videos and links. Today's seminarians are tomorrow's Church leaders and therefore they should learn the right use of social media and various apps so that these means can be put to the best use for Church's mission. Seminarians have to become example for others in the use of social media. If they are credible users of the media and apps, they can demand the same from others. Seminarians are in a position where they are noticed and held in high esteem by people. There are those youth and children closely observing them and wanting to imitate them. Therefore, seminarians should be careful in the use of the social media and make sure that they don't become a cause of scandal to others. Be prudent in posting videos and links as they will be watched and shared by others.

Media education should become part of the seminary curriculum. Instead of preventing access to social media, they should be taught to use the media responsibly. They have to learn the pastoral possibilities and implication of internet and social media. They should know both the positive and negative aspects of digital media, and teach them to develop high moral consciousness in their social media interactions. Since many of them being young may fall into the trap of internet and social media, proper and prudent use of the social media in their ministry should be the objective of the course.

Seminarians have to be encouraged to create, share and engage with online content on a daily basis. They have to be challenged to use media creatively, responsibly and judiciously with the view to expand their horizons of information, knowledge, learning, and further research and study on relevant matters. Injudicious use of social media will distract them in their life and mission and will be detrimental to their moral and Christian living. Therefore, while they are made aware of the dangers of excessive use, the focus has to be on the positive use of social media, and not the shadow side.

\section{DIGITAL ENHANCEMENT OF THE HOLY MASS FOR YOUTH}

Over the last one decade, there have been discussions and debates about virtual sacraments. If we look up on Google, we can find links and posts on this topic since 2009. People have entered into discussions about "virtual Eucharist" and "virtual confession" for quite some time. The liturgists of the Catholic Church have discouraged discussions on these matters. Somewhere along the line, around the year 2014 or so, people involved with digital ministry acknowledged the power of technology in the preparation of sacraments and other related needs. And then, of course, a debate emerged on the possibility of receiving the sacraments online. They argue that if social media can help the preparation of sacraments, why they can't receive sacraments like confession online [2].But it's important to distinguish between online preparation and online participation (like tweeting and live streaming) from online reception of the sacrament. Internet evangelizer and Catholic convert Brantly Millegan argues strongly against the possibility of receiving sacraments online. He says, "Even if the world became a voluntary matrix, where everyone only interacted in a virtual realm, the sacraments would still require us to be physically present to receive them. You must be actually baptized, physically, with real water" [25]. However, it's beyond any doubt that internet is replacing the real world with a virtual world. There will be more of e-books, e-games, e-shopping, internet banking and virtual class rooms in the future. The possibility of e-worship and echurch cannot be ruled out in the future. There will be a substantial increase in the use of social media and internet for liturgy and worship in the Church. Live streaming of Holy Mass and other sacraments enables the homebound and disabled to be part of the celebration from the confines of their rooms. This is a great consolation for those who can't make it to the church.

In the future, it will be difficult to differentiate between tangible and virtual; genuine and fake. With the increase in online ministry we can expect a decline in the physical presence of the faithful in the churches. With this we will also witness content that is superficial and presentations that are merely glamorous. Relationships will lack depth and faith representations will be more secular. It will be a challenge for many to keep pace with the internet and social media revolution that's happening around. 


\section{EMBRACING DIGITALIZATION TO ATTRACT YOUTH TO RELIGION}

Today millions of people are running towards social networking sites like Facebook and Twitter to participate in the relational components of the internet. While most people engage in or wanting to be part of these social networking sites, the question to be answered is whether this is the next big mission field or is it an enormous waste of time? Should a Christian participate in social networking ? The answer to these questions should be determined by whether we can honestly use these media for God's purpose. Saint Paul reminds: "Then, whether you eat or drink, or whatever you do, do it for the glory of God" (1 Corinthians $10: 31)$.*

If we are willing to let God use our participation for His glory, we not only have freedom but we also have the duty to participate in the digital media. God the Father gave his Son Jesus as a gift to the humanity to be shared among all. The humanity today is gifted with modern technologies which are meant to be shared among the members. When a gift is used according to the wish of the gift-giver, the gift-giving becomes more meaningful and purposeful. God the giver of all gifts will be contented when modern technologies are used to disseminate the Gospel values.

It's a good sign that the Catholic Church is taking the youth more seriously now. They are capable of accomplishing much for church's evangelization mission. Campbell [26] speaks of the ways young people use the types of digital story telling in producing faith stories in the context of religious institutions. Digital media enable individuals to integrate religious aspects of their identity into other spheres of everyday life. They are able to mediate between traditional and cultural specific values, identities and norms. In doing so, the youth will adopt means of social media that could be different from the traditional ways. By being different in their ways of functioning, attitude, beliefs and tastes, the youth of our time cannot be considered wrong. They are just being different. Older generation have to make efforts to understand them and embrace them with their differences. Once the youth feel understood and welcomed, they will take initiatives to connect all members of the church through digital media. They will organize exciting programs that will attract youth to the parish church and ensure greater participation of members. The more trust and freedom they enjoy, the greater their commitment and belongingness and much can be accomplished in the Church through them and social media.

\section{CONCLUSION}

Christianity is a religion that is centred on community and Church is an assembly of believers. Jesus announced the standard declaring that God is present where two or three are gathered in his name (Matthew 18:20). ${ }^{*}$ This is possibly an invitation to join the social networking sites where many people are actively present. Social media invites us to engage with others. It provides opportunities for sharing faith and modelling Christian life to new horizons. The gift of technology will indeed be an enviable gift if these media can be fully utilized for gathering members and sharing Good News.

Ever since social media has become part of everyone's life, it is also part of the faith community and part of the ministry [2]. There is no denying the fact that social media and digitalization play a significant role in the faith formation of the young generation. It has made inroads into religious practices and worship. It has made religious sharing and communication easier besides providing opportunities for all including the homebound to be part of the parish community. Most of the worshipping community, particularly the young people are looking for change and want to adopt new technology into their practice of faith and worship. However, Christians who choose to participate in social networking should be aware of the shadow side of social media too. It should be remembered that not everyone on the Internet and social media has pure motives. Church acknowledges that internet and social media can complement and enrich religious life, but it cannot substitute for real community, the sacraments, preaching or embodied experience [27]. The church apps are like 'church in your pocket'. If St Paul used his letters as the means of communicating with people and churches, today it is the digital media that should play the role. 


\section{REFERENCES}

1. Pope Francis. Reuters. 2016 January 22. Retrieved on 2018 January 9 from https://in.reuters.com/article/reuters-america-news-schedule-morning/reuters-america-news-plan-forfriday-jan-22-idINL2N15610Y

2. Gould M. The Social Media Gospel: Sharing the Good News in New Ways. $2^{\text {nd }}$ ed. Minnesota: Liturgical Press; 2015.

3. Merriam-Webster. 2017 December 31. Retrieved on 2018 January 8 from https://www.merriamwebster.com/dictionary/social\%20media

4. Taprial V, Kanwar P. Understandig Social Media. Bookboon; 2012.

5. Hoover SM, Clark LS, Rainie L. Faith online. Pew Internet \& American Life Project. 2004. Retrieved on 2018 January 27 from http://www.pewinternet.org/files/pdf.

6. Larsen E. Wired churches, wired temples: Taking congregations and missions into cyberspace, Pew Internet \& American Life Project: Online life report. 2000 December. Retrieved on 2018 January 27 from http://www.pewinternet.org/files/old-media/Files/Reports/2000/PIP_Religion_Report.pdf.pdf

7. Pope John Paul II. Proclaiming Christ in the Media at the Dawn of the New Millennium. 2000 June 4. Retrieved on 2018 January 28 from http://w2.vatican.va/content/john-paulii/en/messages/communications/documents/hf_jp-ii_mes_20000124_world-communications-day.html

8. Pope Paul VI. EvangeliiNuntiandi. 1975 December 8. Retrieved on 2018 January 28 from http://w2.vatican.va/content/paul-vi/en/apost_exhortations/documents/hf_p-vi_exh_19751208_evangeliinuntiandi.html

9. Stokel-Walker C. How smartphones and social media are changing Christianity. 2017 February 27. Retrieved on 2018 January 28 from http://www.bbc.com/future/story/20170222-how-smartphones-andsocial-media-are-changing-religion

10. Cheong HP, Halavais A, Kwon K. The chronicles of me: Understanding blogging as a religious practice. Journal of Media and Religion 2008;7:107-131.

11. Teusner PE. Emerging church bloggers in Australia: prophets, priests and rulers in God's virtual world. Melbourne: RMIT University, 2010. PhD Thesis.

12. Koh A. The pros and cons of reading the Bible on your smartphone. 2016 October 5. Retrieved on 2018 January 25 from https://growingfaith.com.au/parenting/the-pros-and-cons-of-reading-the-bible-on-yoursmartphone

13. LeVitus B. Incredible iPhone Apps For Dummies. Hoboken, NJ: Wiley Publishing, Inc.; 2010.

14. Lenhart A, Madden M, Smith A, Purcell K, Zickuhr K, Rainie L. Teens, kindness and cruelty on social network sites: How American teens navigate the new world of digital citizenship. Pew Research Center: Internet \& Technology. 2011 November 9. Retrieved on 2018 January 16 from http://www.pewinternet.org/2011/11/09/teens-kindness-and-cruelty-on-social-network-sites/

15. Anonymous. Christians admonished to make effective use of Social Media for God's work. 2016 December 31. Retrieved on 2018 January 29 from https://www.ghanaweb.com/GhanaHomePage/religion/Christians-admonished-to-make-effective-use-ofSocial-Media-for-God-s-work-497877

16. Campbell H. Challenges created by online religious networks. Journal of Media and Religion 2004;3(2):8199.

17. Young G. Reading and praying online: the continuity in religion online and online religion in internet Christianity. In: Lorne LW, Douglas EC. eds. Religion Online: Finding Faith on the Internet. New York: Routledge, 2004; 93-106.

18. Campbell H. Exploring Religious Community Online: We Are One in the Network. New York: Peter Lang; 2005.

19. Smith P. Online Mission and Ministry: A Theological and Practical Guide. London: SPCK; 2015.

20. Estes D. SimChurch: Being the Church in the Virtual World. Grand Rapids: Zondervan; 2009.

21. Heidkamp B. Kergel D. From E-Learning to eBologna in an Augmented Reality: The Past and the Future of E-Learning in German Higher Education. In: Kergel D, Heidkamp B, Telléus P K, Rachwal T, Nowakowski S. eds. The Digital Turn in Higher Education: International Perspectives on Learning and Teaching in a Changing World. Wiesbaden, Germany: Springer VS; 2018.

22. Johari M. Digitalization of Education: Great Change in Teaching-Learning Trends. 2013 July 27. Retrieved on 2018 January 30 from http://scholarship-positions.com/blog/digitization-of-education-great-changeteaching-learning-trends/201307/

23. Mukerji S, Tripathi P. Handbook of Research on Administration, Policy, and Leadership in Higher Education. IGI Global: Hershey, PA; 2017.

24. Ahmed G. Digitalization of Education - For the better or the worse...? 2015 February 27. Retrieved on 2018 January 31 from https://www.linkedin.com/pulse/digitalization-education-better-worse-gayaz-ahmed

25. Sockey D. There's One Thing That We Will Never Be Able to Do Online: the Sacraments. National Catholic Register 2015 April 13. Retrieved on 2018 January 30 from http://www.ncregister.com/dailynews/theres-one-thing-that-we-will-never-be-able-to-do-online-the-sacraments

26. Campbell HA. ed. Digital Religion: Understanding Religious Practice in New Media Worlds. New York: Routledge, 2012. 
27. Foley JP. The Church and Internet. 2002 February 22. Retrieved on 2018 January 31 from http://www.vatican.va/roman_curia/pontifical_councils/pccs/documents/rc_pc_pccs_doc_20020228_chur ch-internet_en.html

*The New Christian Community Bible. Mumbai: St Pauls; 2008.

$* * * * * * * * * * * * * * * * * * * * * * * * * * * * *$

Acknowledgements - Nil

Conflict of Interest - Nil

Funding - Nil 